\title{
Antioxidant activity of nine medicinal plants with commercial potential
}

\author{
Actividad antioxidante de nueve plantas medicinales con potencial comercial
}

Juan Trevizan ${ }^{1}$, Emilio Soto ${ }^{1}$,Felipe Parra ${ }^{1}$, Luis Bustos ${ }^{2}$, Claudio Parra ${ }^{*}$

\begin{abstract}
Nine plants from the Puna ecoregion of northern Chile, traditionally used in ethnomedicine, were studied. The total content of phenolic compounds and their antioxidant capacity (ABTS, FRAP, and ORAC) were determined both in the dry material and in the infusions. To our knowledge, this is the first report on the antioxidant capacity for some of these plants and their infusions. Furthermore, these results show the diversity and complexity of the plants of the Chilean highlands with high potential to be used as a source of natural antioxidants in the reformulation and development of healthier foods.
\end{abstract}

Keywords: antioxidant activity, medicinal infusion, Northern Chile, Phenolic compounds.

\section{RESUMEN}

Se estudiaron nueve plantas de la ecorregión de puna del norte de Chile, utilizadas tradicionalmente en etnomedicina. El contenido total de compuestos fenólicos y su capacidad antioxidante (ABTS, FRAP y ORAC) se determinaron tanto en el material seco como en las infusiones. Según nuestro conocimiento, este es el primer informe sobre capacidad antioxidante para algunas de estas plantas y sus infusiones. Además, estos resultados muestran la diversidad y complejidad de las plantas del altiplano chileno con alto potencial para ser utilizadas como fuente de antioxidantes naturales en la reformulación y el desarrollo de alimentos más saludables.

Palabras clave: actividad antioxidante, infusiones medicinales, compuestos fenólicos.

\section{Introduction}

The use of medicinal plants to treat diseases is probably the oldest method that has been used to treat or deal with a disease. In South America, Andean communities have consumed medicinal plants as an alternative to traditional medicine over the decades, who prepared infusions, decoctions and wound dressings from it (Gastaldi et al., 2018; Villagrán and Castro, 2003). Some plants grow in habitats with altitudes ranging from 500 to 5000 meters above sea level in countries such as Chile, Argentina, Peru, Bolivia, Ecuador, Colombia, and Venezuela. In particular, the Andean communities of northern Chile and suburban societies, historically, have used medicinal plants as an interesting source of therapeutic agents (Table 1) (Moreira-Muñoz et al., 2016), such as Senecio nutans (Asteraceae), which is widely used for mountain sickness characterized by symptoms such as headaches, dizziness, vomiting, and fatigue (Paredes et al., 2016). Another genus of interest is the Parastrephias (Asteraceae). This genus has five different species: P. lucida, P. lephidophylla, $P$. phyllicaeformis, $P$. quadrangularis and P. teretiuscula (Cabrera, 1978). Most of these species are used by the native of the high Andes to relieve among other uses toothache, fractures, and bruises of bones (Villagrán et al., 2003). For many of these species have been reported multiple biological activities found in alcoholic extracts, such as anti-inflammatory activity, antioxidant, antibacterial, as well as the antifungal activity (Di Ciaccio et al., 2018; Echiburu-Chau et al., 2017; Zampini et al., 2009). In the last decade, studies on antioxidant activities of medicinal plants have increased remarkably due to increased interest of the healthy food industry in their potential of being

\footnotetext{
Facultad de Ciencias Agronómicas, Universidad de Tarapacá. Arica, Chile.

2 Escuela de Medicina, Facultad de Ciencias de la Salud, Universidad de Tarapacá. Arica, Chile.

* Corresponding author: cparra@uta.cl
} 
Table 1. Ethnobotanical data of the selected Andean plants from northern Chile.

\begin{tabular}{llllll}
\hline $\begin{array}{c}\text { Plant } \\
\text { specie }\end{array}$ & Family & $\begin{array}{c}\text { Common } \\
\text { name }\end{array}$ & $\begin{array}{c}\text { Voucher } \\
\text { number }\end{array}$ & $\begin{array}{c}\text { Part } \\
\text { used }\end{array}$ & \\
\hline Aldama helianthoides & Asteraceae & Sorona & 184923 & Stems, leaves & $\begin{array}{c}\text { Traditional } \\
\text { uses }\end{array}$ \\
\hline Aloysia tarapacana & Verbenaceae & Rika-Rika & 184924 & Aerial parts & Anti-rheumatic, cancer, hepatitis, lower cholesterol \\
\hline Azorella compacta & Apiaceae & Llareta & 169936 & Roots, flowers, seeds and resin & Diuretic, analgesic, diabetes, pneumonia \\
\hline Baccharis alnifolia & Asteraceae & Chilka & 184925 & Whole plant, leaves & Bonepain, indigestión, anti-inflammatory, anti-rheumatic \\
\hline Baccharis tola & Asteraceae & Nacatola & 184926 & Aerial parts, leaves and stems & Gastro protective, Antiseptic, anti-inflammatory \\
\hline Clinopodium gilliesii & Lamiaceae & Muña & 184929 & Aerial parts & Digestive disorders, altitude sickness, aphrodisiac \\
\hline Dunalia spinosa & Solanaceae & Yara & 184931 & Leaves, fruits, Flowers & Diabetes, antiseptic, high altitude sickness \\
\hline Parastrephia lucida & Asteraceae & Umatola & 184936 & Whole plant & Broken bones, analgesic, antiseptic, anti-inflammatory \\
\hline Polylepis tarapacana & Rosaceae & Queñoa & 179704 & Bark, leaves & Respiratory diseases, diabetes, hypertension \\
\hline
\end{tabular}

used as a rich and natural source of antioxidants (Gonçalves et al., 2013; Li et al., 2013). However, many Andean plants have not been studied in their most common form of consumption such as decoction or infusion. This work aimed to determine the transfer of phenolic compounds and antioxidant activity in nine medicinal plants from northern Chile which could be used for the reformulation and the development of healthier food.

\section{Materials and methods}

\section{Collection and sample preparation}

Fresh aerial parts of these plants were collected from March to May 2019 from Andean Altiplano, northern Chile (3000 to 4100 m.a.s.1.). Each voucher specimens were deposited in the Herbarium from the Botany Department of the Universidad de Concepción, Chile. The fresh aerial parts of these plants were brought to the laboratory for drying at room temperature. After the drying process, the leaves were removed manually from the stems and then stored in airtight polyethylene bags until its use.

\section{Ethanolic extraction}

Dried and powdered aerial parts of each plant $(1 \mathrm{~g})$ were extracted with absolute ethanol for 30 minutes in the dark in an ultrasonic bath $(100 \mathrm{~mL}$, three times) to obtain an extract for total phenolics and flavonoid content and antioxidant analyses. The extract was immediately concentrated under vacuum.

\section{Infusion extraction}

Each infusion was prepared from the whole herb (stem and leaves), using $0.5 \mathrm{~g}$ of plant brewed for 5 minutes in $250 \mathrm{~mL}$ water at $100^{\circ} \mathrm{C}$ (Soto et al., 2019). The infusion was left to cool at room temperature and tested for bioactive compounds on the same day.

\section{Total polyphenol and flavonoid contents}

Total polyphenolic contents (TPC) were determined by the Folin-Ciocalteau method as reported (Parra et al., 2018). Determination of total flavonoid content (TFC) of the resin was performed as previously described (Parra et al., 2018).

\section{Antioxidant assays}

To measure the antioxidant activity of nine plants, we used the FRAP, TEAC, and ORAC assays. Every analysis was performed in BioTek Synergy HTX Multi-Mode Microplate Reader (Winooski, VT, USA) using 96-well microplates. For all antioxidant assays, a standard curve of Trolox was used, and results were expressed as Trolox equivalents gram dry weight (mmol TE/g of DW). The FRAP and TEAC assays were performed according to Soto with modifications (Soto et al., 2019).

\section{Statistical analysis}

All analyses were carried out in triplicate, and data are presented as means and standard 
Table 2. Phenolic compounds, total flavonoids and antioxidant activities of the selected Andean plants from northern Chile.

\begin{tabular}{|c|c|c|c|c|c|c|}
\hline \multirow{2}{*}{ Plant specie } & \multirow{2}{*}{$\begin{array}{l}\text { Yield } \\
(\%)\end{array}$} & \multirow{2}{*}{$\begin{array}{c}\text { TPC } \\
(\mathrm{mg} \mathrm{GAE} / \mathrm{g} \mathrm{DW})\end{array}$} & \multirow{2}{*}{$\begin{array}{c}\text { TFC } \\
(\mathrm{mg} \mathrm{QE} / \mathrm{g} \mathrm{DW})\end{array}$} & \multicolumn{3}{|c|}{ TEAC $(\mu \mathrm{mol}$ TE/g DW $)$} \\
\hline & & & & FRAP & ABTS & ORAC \\
\hline Aldama helianthoides & 6.6 & $7.40=$ & $6.91=$ & $53.74 \pm 1.54^{\mathrm{f}}$ & $16.69 \pm 0.03^{\mathrm{d}}$ & $126.37 \pm 0.01^{\mathrm{d}}$ \\
\hline Aloysia tarapacana & 19.8 & $16.55 \pm 0.15^{\mathrm{f}}$ & $7.02 \pm 0.23^{\mathrm{cd}}$ & $50.56 \pm 0.76^{\mathrm{df}}$ & $29.89 \pm 0.06^{f}$ & $130.31 \pm 0.01^{\mathrm{e}}$ \\
\hline Azorella compacta & 3.4 & $8.63 \pm 0.15^{\mathrm{d}}$ & $7.84 \pm 0.11^{\mathrm{cde}}$ & $41.35 \pm 0.19^{\mathrm{cd}}$ & $14.62 \pm 0.03^{c}$ & $53.79 \pm 0.01^{b}$ \\
\hline Baccharis alnifolia & 12.7 & $4.42 \pm 0.06^{b}$ & $1.24 \pm 0.24^{\mathrm{a}}$ & $13.29 \pm 0.61^{\mathrm{b}}$ & $6.19 \pm 0.03^{\mathrm{ab}}$ & $170.64 \pm 0.01 \mathrm{~g}$ \\
\hline Baccharis tola & 24.6 & $27.10 \pm 0.33^{g}$ & $8.36 \pm 0.40^{\mathrm{ef}}$ & $52.21 \pm 2.81^{\text {cdef }}$ & $30.86 \pm 0.11^{\mathrm{fg}}$ & $98.95 \pm 0.01^{\mathrm{c}}$ \\
\hline Clinopodium gilliesii & 7.9 & $14.46 \pm 0.23^{\mathrm{e}}$ & $11.26 \pm 0.14 \mathrm{~g}$ & $95.67 \pm 1.21^{\mathrm{g}}$ & $19.84 \pm 0.06^{\text {abe }}$ & $51.55 \pm 0.01^{\mathrm{a}}$ \\
\hline Dunalia spinosa & 4.3 & $2.44 \pm 0.09^{\mathrm{a}}$ & $1.54 \pm 0.02^{\mathrm{ab}}$ & $6.91 \pm 0.07 \mathrm{ab}$ & $4.80 \pm 0.05^{\mathrm{ae}}$ & $137.15 \pm 0.18^{f}$ \\
\hline Parastrephia lucida & 35.0 & $77.80 \pm 0.38^{i}$ & $73.17 \pm 1.19^{\mathrm{i}}$ & $816.92 \pm 5.46^{\mathrm{i}}$ & $185.85 \pm 2.44^{\mathrm{i}}$ & $2904.38 \pm 0.01^{\mathrm{i}}$ \\
\hline Polylepis tarapacana & 12.1 & $55.17 \pm 0.10^{\mathrm{h}}$ & $24.37 \pm 0.20^{\mathrm{h}}$ & $473.68 \pm 0.55^{\mathrm{h}}$ & $139.05 \pm 0.33^{\mathrm{h}}$ & $2352.91 \pm 0.01^{\mathrm{h}}$ \\
\hline
\end{tabular}

* Superscript letters indicate significant differences $(\mathrm{p}<0.05$, one-way ANOVA).

deviations (SD). GraphPad Prism® 6 software was used for statistical analysis of the experimental data. One-way analysis of variance (ANOVA) was used for statistical analysis, where $p<0.05$ were considered statistically significant.

\section{Results and discussion}

\section{Bioactive compounds and antioxidant activity of the selected medicinal plants}

Among the different phytochemicals in existence, phenolic compounds have been in the privileged spot for the last years, being studied and used in different application areas such as food, health, and pharmaceutical industries (Chirinos et al., 2013). This work assessed the total polyphenol content (TPC), total flavonoid content (TFC), and antioxidant activity of nine medicinal plants from northern Chile used as an infusion. Polyphenol quantification in the ethanolic extracts of the plants studied (2.44 to $77.80 \mathrm{mg}$ GAE/g DW), they revealed that values fell into the range reported in the literature for medicinal Chinese plants $(\mathrm{Li}$ et al., 2013), medicinal Andean plants (Chirinos et al., 2013), as well as in the range of the herbal tea (Oh et al., 2013), and Asian tropical plant $G$. velutinus from Brunei Darussalam (Iqbal et al., 2015), both considered rich polyphenol sources.

Since the antioxidant activity of a plant extract is determined by a mixture of compounds, it is convenient to evaluate this property through more than one method (Pisoschi et al., 2016). Therefore, here we used the single electron transfer (SET) method, such as FRAP; as well as hydrogen atom transfer (HAT) in the ABTS and ORAC (Liang and Kitts, 2014). The FRAP values fluctuated between 6.91 to $816.92 \mu \mathrm{mol} \mathrm{TE} / \mathrm{g}$ DW (Table 1), slightly less when compared to those reported for other medicinal plants (Jiménez et al., 2015), but with values higher than those reported for Indian medicinal plants (Surveswaran et al., 2007). While that the values of ABTS were between 4.80 to $185.85 \mu \mathrm{mol}$ TE/g DW, these values were similar or superior to those reported in the literature for different medicinal plants from China (Li et al., 2013). In the cases of ORAC values, P. lucida and $P$. tarapacana showed a high antioxidant capacity similar to Chilean berries, they are recognized by their powerful antioxidant activity (Chamorro et al., 2019).

\section{Bioactive compounds and antioxidant activity of the medicinal plant infusions}

Three have been found report in the literature that describes the antioxidant capacity in infusions of medicinal plants from northern Chile (Larrazabal et al., 2018; Rojo et al., 2009; Soto et al., 2019). The differences between this study and others may be due to the different sites and times of the plants collection (Jordán et al., 2013), as well as, to an important extent, the mass:water ratio used and the different aqueous extraction methods. These results clearly show that not only the total content of bioactive compounds of the plants is important for the estimation of the therapeutic or toxic effects, but also the actual protocol of intake (Nischwitz et al., 2017). The infusions were prepared with $0.5 \mathrm{~g}$ plant material for $5 \mathrm{~min}$ in $250 \mathrm{~mL}$ hot water. For brewing times over $5 \mathrm{~min}$, a reduction in TPC could be observed, possibly due 
to the thermolability of the compounds (Larrazabal et al., 2018). To our knowledge, the antioxidant activity of many of these infusions have not been studied or lower values have been published than those found in this study. The polyphenol content found these herbs ranged from $27.80-567.50 \mathrm{mg}$ GAE/L (see Table 3). The infusion of P. lucida showed the highest content of phenolic compounds, it followed B. tola, D. spinosa and A. compacta, all these plants have potential as antioxidant infusions. Moreover, the values found in this study were considerably higher than the value literature reported for the same plants (Rojo et al., 2009). The value of $\mathrm{QE}$ for $\mathrm{P}$. lucida was considerably higher than those of Green Tea, and this value was the highest of all the plants analyzed. The content of flavonoids is similar to that reported in infusions of native plants of Argentine Patagonia (Gastaldi et al., 2018). TPC and AC are correlated (Table 4), with correlation coefficients for FRAP (0.8648), ABTS (0.9453), and ORAC (0.9500) similar to reported for another medicinal plant (Berłowski et al., 2013; Surveswaran et al., 2007). These correlations implied that phenolic compounds in these extracts could be the main components contributing to scavenging free radical activities, but not be responsible for reducing oxidant abilities. Moreover, the data showed that the antioxidant capacities measured by ABTS assay are strongly correlated with the ORAC (0.9065). The FRAP values fluctuated from 297.9 to $2164.25 \mu \mathrm{mol}$ TE/L, however, the values found in other herbs which grow on the Chilean Altiplano under the same agroclimatic conditions, they were far greater than the value obtained here (Rojo et al., 2009). This difference could be attributed to the concentration of the infusions used in previous reported. In this work, it was used samples that are much closer to the real conditions under which an infusion for direct human consumption is prepared. TPC and FRAP reflect the presence of all the reducing substances in a given matrix, not just the polyphenolic compounds. Therefore, interpretations of these results should be considered as potential limitations. To strengthen our results, we have analyzed the antioxidant capacity through the ABTS and ORAC assays. ABTS assay showed values between 178.25 to $2426.65 \mu$ mol TE per liter (see Table 3). The values found in this work are below those reported for medicinal plants

Table 3. Yields, antioxidant activity and toxic elements of 9 Andean infusion tea plant extracts from northern Chile.

\begin{tabular}{|c|c|c|c|c|c|c|}
\hline \multirow{2}{*}{ Plant specie } & \multirow{2}{*}{$\begin{array}{l}\text { Yield } \\
(\%)\end{array}$} & \multirow{2}{*}{$\begin{array}{c}\text { TPC } \\
\text { (mg GAE/L) }\end{array}$} & \multirow{2}{*}{$\begin{array}{c}\text { TFC } \\
(\mathrm{mg} \mathrm{QE} / \mathrm{L})\end{array}$} & \multicolumn{3}{|c|}{ TEAC $(\mu \mathrm{mol} \mathrm{TE} / \mathrm{L})$} \\
\hline & & & & FRAP & ABTS & ORAC \\
\hline Aldama helianthoides & 6.6 & $27.80 \pm 0.10^{\mathrm{a}}$ & $27.50 \pm 0.20^{c}$ & $347.50 \pm 1.90^{\mathrm{b}}$ & $270.70 \pm 2.65^{b}$ & $89.3 \pm 0.05^{\mathrm{a}}$ \\
\hline Aloysia tarapacana & 6.2 & $123.15 \pm 0.35^{\mathrm{de}}$ & $61.85 \pm 0.95^{\mathrm{e}}$ & $1071.00 \pm 5.65^{\mathrm{g}}$ & $900.95 \pm 9.90 \mathrm{~g}$ & $930.00 \pm 1.40^{\mathrm{e}}$ \\
\hline Azorella compacta & 8.3 & $169.10 \pm 4.60^{f}$ & $76.95 \pm 2.90 \mathrm{~g}$ & $516.85 \pm 23.55^{\mathrm{c}}$ & $288.15 \pm 22.45^{\mathrm{bc}}$ & $1106.50 \pm 10.15^{f}$ \\
\hline Baccharis alnifolia & 10.3 & $35.85 \pm 0.60^{\mathrm{ab}}$ & $8.05 \pm 0.30^{\mathrm{a}}$ & $618.75 \pm 8.80^{\mathrm{d}}$ & $546.25 \pm 11.55^{\mathrm{e}}$ & $599.50 \pm 0.15^{d}$ \\
\hline Baccharis tola & 8.9 & $225.6 \pm 5.80^{\mathrm{h}}$ & $71.65 \pm 0.70^{\mathrm{efg}}$ & $2164.25 \pm 8.35^{\mathrm{h}}$ & $1772.45 \pm 13.20^{\mathrm{h}}$ & $1145.75 \pm 8.20 \mathrm{~g}$ \\
\hline Clinopodium gilliesii & 4.3 & $81.80 \pm 1.10^{c}$ & $79.35 \pm 1.45^{\text {fgh }}$ & $664.75 \pm 3.50^{\mathrm{e}}$ & $430.60 \pm 3.30^{\mathrm{d}}$ & $259.95 \pm 0.05^{\mathrm{b}}$ \\
\hline Dunalia spinosa & 24.5 & $172.40 \pm 0.40 \mathrm{~g}$ & $9.85 \pm 0.15^{\mathrm{ab}}$ & $1001.60 \pm 1.75^{\mathrm{f}}$ & $716.80 \pm 8.25^{f}$ & $1427.75 \pm 9.15^{\mathrm{h}}$ \\
\hline Parastrephia lucida & 18.3 & $567.50 \pm 4.00^{\mathrm{i}}$ & $335.30 \pm 7.75^{\mathrm{i}}$ & $3566.85 \pm 8.35^{\mathrm{i}}$ & $2426.65 \pm 13.20^{\mathrm{i}}$ & $5400.45 \pm 20.26^{\mathrm{i}}$ \\
\hline Polylepis tarapacana & 6.4 & $109.55 \pm 1.35^{\mathrm{d}}$ & $51.55 \pm 2.75^{\mathrm{de}}$ & $297.90 \pm 1.05^{\mathrm{a}}$ & $178.25 \pm 3.20^{\mathrm{a}}$ & $591.10 \pm 0.95^{\mathrm{c}}$ \\
\hline
\end{tabular}

*Superscript letters indicate significant differences ( $\mathrm{p}<0.05$, one-way ANOVA).

Table 4. Coefficients for the correlation between antioxidant capacities measured by ABTS, FRAP and ORAC assays, total phenolics and flavonoids content of 9 medicinal infusions from northern Chile.

\begin{tabular}{llllcc}
\hline & ABTS & FRAP & ORAC & Phenolics & Flavonoids \\
\hline ABTS & 1 & 0.9787 & 0.9065 & 0.9453 & 0.8158 \\
FRAP & 0.9787 & 1 & 0.8057 & 0.8648 & 0.7266 \\
ORAC & 0.9065 & 0.8057 & 1 & 0.9500 & 0.8562 \\
Phenolics & 0.9453 & 0.8648 & 0.9500 & 1 & 0.8620 \\
Flavonoids & 0.8158 & 0.7266 & 0.8562 & 0.8620 & 1 \\
\hline
\end{tabular}


from Peru (Berłowski et al., 2013). The results for ORAC assay showed values between 89.30 to $5400.45 \mu \mathrm{mol}$ TE/L. The medicinal infusions of Andean northern Chile were similar than reported for the black and green tea (Floegel et al., 2011).

\section{Conclusion}

The antioxidant capacities and total phenolics and flavonoids contents of nine infusions medicinal plants from northern Chile were evaluated using the FRAP, ABTS and ORAC assays as well as the Folin-Ciocalteu and aluminum trichloride methods, respectively. The antioxidant activity found suggests that compared to SET assays the HAT assays better estimate the antioxidant capacity of these beverages. The data show that the antioxidant capacities measured by ABTS assay are strongly correlated with the ORAC and phenolic compounds. P. lucida showed the highest antioxidant capacities and total phenolic contents. Moreover, B. tola, D. spinosa and A. compacta, all these plants have potential as antioxidant infusions, being similar to those of green tea.

\section{Acknowledgments}

This study was supported by Universidad de Tarapacá.

\section{Literature Cited}

Berłowski, A.; Zawada, K.; Wawer, I.; Paradowska, K. 2013. Antioxidant properties of medicinal plants from Peru. Food and Nutrition Sciences, 4: 71.

Cabrera, A.

1978. Flora de la Provincia de Jujuy.Coleccion cientifica del INTA, 13 (10): 9-726.

Chamorro, M.F.; Reiner, G.; Theoduloz, C.; Ladio, A.; Schmeda-

Hirschmann, G.; Gómez-Alonso, S.; Jiménez-Aspee, F. 2019. Polyphenol Composition and (Bio) Activity of Berberis Species and Wild Strawberry from the Argentinean Patagonia. Molecules, 24: 3331.

Chirinos, R.; Pedreschi, R.; Rogez, H.; Larondelle, Y.; Campos, D.

2013. Phenolic compound contents and antioxidant activity in plants with nutritional and/or medicinal properties from the Peruvian Andean region. Industrial Crops and Products, 47: 145-152.

Di Ciaccio, L.; Spotorno, V.; Córdoba Estévez, M.; Ríos, D.; Fortunato, R.; Salvat, A.

2018. Antifungal activity of Parastrephia quadrangularis (Meyen) Cabrera extracts against Fusarium verticillioides. Letters in applied microbiology, 66: 244-251.

Echiburu-Chau, C., Pastén, L., Parra, C., Bórquez, J., Mocan, A., Simirgiotis, M.J.

2017. High resolution UHPLC-MS characterization and isolation of main compounds from the antioxidant medicinal plant Parastrephia lucida (Meyen). Saudi Pharmaceutical Journal, 25(7): 1032-1039.

Floegel, A.; Kim, D.-O.; Chung, S.-J.; Koo, S.I.; Chun, O.K.; 2011. Comparison of ABTS/DPPH assays to measure antioxidant capacity in popular antioxidant-rich US foods. Journal of food composition and analysis, 24: 1043-1048.

Gastaldi, B.; Marino, G.; Assef, Y.; Sofrás, F.S.; Catalán,

C.; González, S.

2018. Nutraceutical Properties of Herbal Infusions from Six Native Plants of Argentine Patagonia. Plant Foods for Human Nutrition, 73: 180-188.

Gonçalves, S.; Gomes, D.; Costa, P.; Romano, A. 2013. The phenolic content and antioxidant activity of infusions from Mediterranean medicinal plants. Industrial Crops and Products, 43: 465-471.
Iqbal, E.; Salim, K.A.; Lim, L.B.

2015. Phytochemical screening, total phenolics and antioxidant activities of bark and leaf extracts of Goniothalamus velutinus (Airy Shaw) from Brunei Darussalam. Journal of King Saud University-Science, 27: 224-232.

Jiménez, N.; Carrillo-Hormaza, L.; Pujol, A.; Álzate, F.; Osorio, E.; Lara-Guzman, O.

2015. Antioxidant capacity and phenolic content of commonly used anti-inflammatory medicinal plants in Colombia. Industrial Crops and Products, 70: 272-279.

Jordán, M.J.; Lax, V.; Rota, M.C.; Lorán, S.; Sotomayor, J.A. 2013. Effect of bioclimatic area on the essential oil composition and antibacterial activity of Rosmarinus officinalis L. Food control, 30: 463-468.

Larrazabal, M.J.; Palma, J.; Paredes, A.; Morales, G.; Mercado, A. 2018. Effect of brewing conditions on pigments and total polyphenols content and biological activities of the Acantholippia deserticola (Phil.) infusion. CyTA-Journal of Food, 16: 588-595.

Li, S.; Li, S.-K.; Gan, R.-Y.; Song, F.-L.; Kuang, L.; Li, H.-B. 2013. Antioxidant capacities and total phenolic contents of infusions from 223 medicinal plants. Industrial Crops and Products 51: 289-298.

Liang, N., Kitts, D.

2014. Antioxidant property of coffee components: assessment of methods that define mechanisms of action. Molecules, 19: 19180-19208.

Moreira-Muñoz, A.; Muñoz-Schick, M.; Marticorena, A.; Morales, V.

2016. Catálogo de Asteraceae (Compositae) de la Región de Arica y Parinacota, Chile. Gayana. Botánica, 73: 226-267. Nischwitz, V.; Mogwasi, R.; Zor, S.; Getenga, Z.; Kariuki, D.K.; Günther, K.

2017. First comprehensive study on total contents and hot water Extractable fraction of selected elements in 19 medicinal plants from various locations in Nyamira County, Kenya. Journal of Trace Elements in Medicine and Biology, 39: 54-61.

Oh, J.; Jo, H.; Cho, A.R.; Kim, S.-J.; Han, J.

2013. Antioxidant and antimicrobial activities of various leafy herbal teas. Food control, 31: 403-409. 
Paredes, A., Palacios, J.; Quispe, C.; Nwokocha, C.R.; Morales, G.; Kuzmicic, J.; Cifuentes, F.

2016. Hydroalcoholic extract and pure compounds from Senecio nutans Sch. Bip (Compositae) induce vasodilation in rat aorta through endothelium-dependent and independent mechanisms. Journal of ethnopharmacology, 192: 99-107.

Parra, C.; Soto, E.; León, G.; Salas, C.O.; Heinrich, M.; Echiburú-Chau, C.

2018. Nutritional composition, antioxidant activity and isolation of scopoletin from Senecio nutans: support of ancestral and new uses. Natural Product Research, 32(6): 719-722.

Pisoschi, A.M.; Pop, A.; Cimpeanu, C.; Predoi, G.

2016. Antioxidant capacity determination in plants and plant-derived products: A review. Oxidative medicine and cellular longevity, 2016(2016): 9130976

Rojo, L.E., Benites, J., Lopez, J., Rojas, M., Diaz, P., Ordoñez,

J., Pastene, E.

2009. Antioxidant capacity and polyphenolic content of twelve traditionally used herbal medicinal infusions from the South American Andes. Boletín Latinoamericano y del Caribe de Plantas Medicinales y Aromáticas, 8: 498-508.

Soto, E.; Bustos, L.; Simirgiotis, M.J.; Parra, C.

2019. Potential of Baccharis alnifolia Meyen \& Walpan (Chilka) from northern Chile used as a medicinal infusion. Ciência Rural, 49(10): e20190428.

Surveswaran, S.; Cai, Y.-Z.; Corke, H.; Sun, M.

2007. Systematic evaluation of natural phenolic antioxidants from 133 Indian medicinal plants. Food chemistry, 102: 938-953. Villagrán, C.; Castro, V.

2003. Ciencia indígena de los Andes del norte de Chile. Editorial Universitaria. Santiago, Chile. 361 p.

Villagrán, C.; Romo, M.; Castro, V.

2003. Etnobotánica del sur de los Andes de la Primera Región de Chile: un enlace entre las culturas altiplánicas y las de quebradas altas del Loa superior. Chungará (Arica), 35: 73-124.

Zampini, I.; Cuello, S.; Alberto, M.; Ordonez, R.; D’Almeida, R.; Solorzano, E.; Isla, M.

2009. Antimicrobial activity of selected plant species from "the Argentine Puna" against sensitive and multi-resistant bacteria. Journal of ethnopharmacology, 124:499-505. 